\title{
Biomass uptake and fire as controls on groundwater solute evolution on a southeast Australian granite: aboriginal land management hypothesis
}

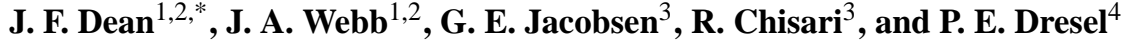 \\ ${ }^{1}$ Agricultural Sciences Department, La Trobe University, Bundoora, Victoria, Australia \\ ${ }^{2}$ National Centre for Groundwater Research and Training, Australia \\ ${ }^{3}$ Institute for Environmental Research, ANSTO, Sydney, Australia \\ ${ }^{4}$ Department of Environment and Primary Industries, Bendigo, Victoria, Australia \\ * now at: Biological and Environmental Sciences, University of Stirling, Scotland
}

Correspondence to: J. F. Dean (joshua.dean@sitr.ac.uk)

Received: 18 December 2013 - Published in Biogeosciences Discuss.: 30 January 2014

Revised: 6 June 2014 - Accepted: 22 June 2014 - Published: 4 August 2014

\begin{abstract}
The chemical composition of groundwater and surface water is often considered to be dominated by waterrock interactions, particularly weathering; however, it has been increasingly realised that plant uptake can deplete groundwater and surface water of nutrient elements. Here we show, using geochemical mass balance techniques, that water-rock interactions do not control the hydrochemistry at our study site within a granite terrain in southwest Victoria, Australia. Instead the chemical species provided by rainfall are depleted by plant biomass uptake and exported, predominantly through fire. Regular landscape burning by Aboriginal land users is hypothesized to have caused the depletion of chemical species in groundwater for at least the past $20000 \mathrm{yr}$ by accelerating the export of elements that would otherwise have been stored within the local biomass. These findings are likely to be applicable to silicate terrains throughout southeast Australia, as well as similar lithological and climatic regions elsewhere in the globe, and contrast with studies of groundwater and surface water chemistry in higher rainfall areas of the Northern Hemisphere, where water-rock interactions are the dominant hydrochemical control.
\end{abstract}

\section{Introduction}

The geochemistry of groundwater has been generally considered to be dominated by water-rock interactions (Garrels and Mackenzie, 1967; Moulton et al., 2000; Pogge von Strandmann et al., 2008; Taylor and Velbel, 1991; Turner et al., 2010; Velbel, 1985; Velbel and Price, 2007; White et al., 2002). However, despite often being in contact with the aquifer rock for long periods of time, groundwater in southeast Australia does not always show strong water-rock interaction signatures (e.g. Bennetts et al., 2006; Edwards and Webb, 2009; Raiber et al., 2009).

Furthermore, it has been increasingly recognised that vegetation can influence the composition of groundwater in two ways. Firstly, through increased weathering rates resulting from low $\mathrm{pH}$ micro-environments around the roots, accelerating the release of elements from rock and soil minerals and encouraging cation exchange; and secondly, through biomass acting as a nutrient sink, exporting chemical species in organic matter that is removed from the system through flooding and fire (Calmels et al., 2011; Cleaves et al., 1970; Edwards and Webb, 2009; Feikema et al., 2012; Moulton et al., 2000; Taylor and Velbel, 1991; Velbel and Price, 2007; White et al., 2002).

$\mathrm{Ca}^{2+}, \mathrm{K}^{+}, \mathrm{HCO}_{3}^{-}, \mathrm{Mg}^{2+}$, and $\mathrm{S}$ (macronutrients), $\mathrm{Si}$ (micronutrients) and $\mathrm{Na}^{+}$(beneficial element) are all utilised by plants and are sourced from the regolith and water infiltrating through it (Atwell et al., 1999; Marschner, 1989; 
Wallace et al., 1979). As a result the infiltrating water can become depleted in these elements, potentially overwriting any water-rock signature in the groundwater and surface water (Edwards and Webb, 2009). To what extent vegetation removes these elements from the system and temporarily locks them up in biomass depends on the vegetation type, whether uptake is consistent year-round, the underlying geology, and the amount of water moving through the system (Moulton et al., 2000; Velbel and Price, 2007).

To assess the relative importance of different processes on the evolution of groundwater and surface water composition as they travel through a hydrological system, geochemical mass balances are commonly used (Bricker et al., 2004; Garrels and Mackenzie, 1967; Locsey et al., 2012; Rasmussen et al., 2011; Velbel and Price, 2007; Wood and Low, 1986). Most geochemical mass balance studies have focused on surface water, looking at the export of chemical species from a system via stream baseflow (e.g. Turner et al., 2010). These present-day (short term) studies look at a snapshot of weathering, extrapolating to consider the broader impacts of silicate weathering on $\mathrm{CO}_{2}$ dynamics over longer timescales (Velbel and Price, 2007). The same mass balance approach can be used to investigate the longer term evolution of groundwater, taking into account the entire chemical evolution that has taken place while the water was beneath the surface (Chapelle, 2010; Locsey et al., 2012; Plummer and Back, 1980; Wood and Low, 1986).

Previous studies on the role of plant uptake in groundwater and surface water chemistry are dominated by high rainfall settings in the Northern Hemisphere. In contrast, the present study is in the much drier southeast of Australia where the vegetation was native Eucalypt forest for the relevant timescale (up to $20000 \mathrm{yr} \mathrm{BP}$ ). This study aims to determine the long term geochemical evolution of groundwater at the study site, and to investigate the role of vegetation uptake within this.

\section{Background}

\subsection{Wider project}

This study is part of a larger paired-catchment investigation into the impacts of tree plantations on the quality and quantity of groundwater and surface water resources in Victoria, Australia (Adelana et al., 2014; Camporese et al., 2013; Dresel et al., 2012). Due to the age of the groundwater (generally $1000-7000 \mathrm{yr}$ old, with a maximum age of $\sim 20000$ yr; see later discussion) it was not possible to use the hydrochemistry to determine the effect of the tree plantation on the water composition, as the trees were planted in July 2008.

\subsection{Study site}

The study area is a pair of small, adjacent catchments, $1.33 \mathrm{~km} 2$ in total, in southwest Victoria, situated on the
Devonian-aged Dwyer Granite, 390-395 Ma old (Fig. 1; Hergt et al., 2007; VandenBerg, 2009). The mineralogy of the Dwyer Granite is dominated by potassium-rich alkalifeldspar, quartz and plagioclase $\left(\mathrm{An}_{18-30}\right.$, with phenocryst cores generally $\sim \mathrm{An}_{25-30}$ ), along with minor biotite, calcic hornblende and accessory phases, the latter including opaque oxides, apatite, allanite, titanite and zircon (Hergt et al., 2007). The upper $\sim 20 \mathrm{~m}$ of the granite is well weathered, porous and permeable saprolite; below this is relatively fresh, fractured bedrock; together saprolite and bedrock form a single, connected aquifer. The fractured granite aquifer extends no deeper than $150 \mathrm{~m}$, as below this depth the fracture conductivity is negligible due to the high lithostatic pressure (Cook, 2003; Boutt et al., 2010; Dept. Sustainability and Environment, 2012). The topography of the site, a series of hills in the middle of a broad valley (Fig. 1), means that both catchments are local ground water systems, and that there are no regional groundwater inputs.

The climate is maritime/temperate, $\mathrm{Cfb}$ in the Köppen classification; the average annual rainfall for the area is $672 \mathrm{~mm}( \pm 125 \sigma)$, while pan evaporation is $1350 \mathrm{~mm}$ annually, exceeding rainfall for the majority of the year, excepting the winter months of May through September (data from Bureau of Meteorology, Hamilton, Australia; Fig. 2). As a result the streams draining the site are dry for most of the year but flow after heavy rain, particularly during winter.

The pre-European vegetation of the area was mostly open Eucalypt woodland (Department of Sustainability and Environment, Victoria; Fig. 3). Following European settlement there was extensive land clearance, and the catchments were entirely converted to pasture by 1869 (White et al., 2003); a Eucalyptus globulus plantation, planted in July 2008, now covers the majority of the northern catchment (Fig. 1). Eucalypt forests are evergreen and transpire and grow throughout the year, but tend to have slower growth and transpiration periods over winter due to decreased sunlight hours.

\section{Methods}

\subsection{Water sampling}

All 23 groundwater bores across the entire site, along with weirs on the streams draining the two catchments, Lambing Hut and Dwyer's Creeks, were sampled once each over a period of a year, August 2010 to August 2011 (Table 1, Fig. 1 - note six are nested bore sites, and are represented by only a single dot). The screened intervals in the bores were mostly in saprolite, but some were in the underlying fresh granite (the granite and saprolite form a single aquifer). Seasonal variability in groundwater composition is considered negligible due to the age of the groundwater at the study site (see Table 1), and repeat sampling produced virtually identical field parameters. For example bore 2278 was sampled twice within the year-long sampling campaign, 3 months apart, and 

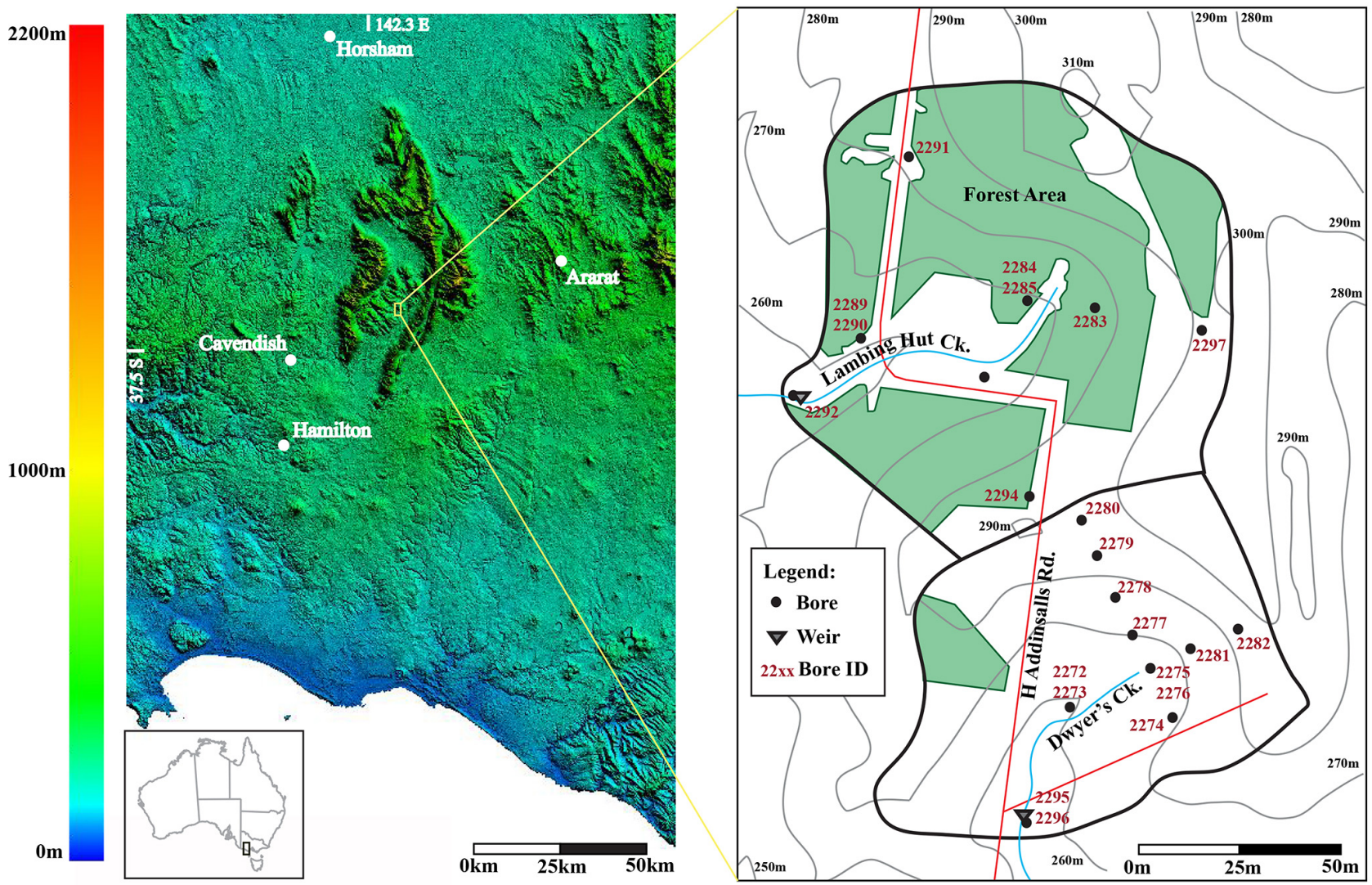

Figure 1. Left - Location of the study site in southwestern Victoria, Australia. Right - location of the bores, streams and weirs.

Table 1. Groundwater and surface water sampling details, field parameters and major ion compositions.

\begin{tabular}{|c|c|c|c|c|c|c|c|c|c|c|c|c|c|c|c|}
\hline $\begin{array}{l}\text { Sample } \\
\text { ID }\end{array}$ & $\begin{array}{l}\text { Date } \\
\text { sampled }\end{array}$ & $\begin{array}{r}\text { Sample } \\
\text { depth } \\
\text { (m below } \\
\text { surface) }\end{array}$ & $\mathrm{pH}$ & $\begin{array}{r}\text { Percent } \\
\text { error of } \\
\text { analyses } \\
\text { (PHREEQC) }\end{array}$ & $\begin{array}{r}\text { Electrical } \\
\text { conductivity } \\
\left(\mu \mathrm{S} \mathrm{cm}^{-1}\right)\end{array}$ & $\begin{array}{r}\text { Dissolved } \\
\text { oxygen } \\
(\mathrm{ppm})\end{array}$ & $\begin{array}{r}\mathrm{Ca}^{2+} \\
\left(\mathrm{mg} \mathrm{L}^{-1}\right)\end{array}$ & $\begin{array}{r}\mathrm{Cl}^{-} \\
\left(\mathrm{mg} \mathrm{L}^{-1}\right)\end{array}$ & $\begin{array}{r}\mathrm{Fe} \\
\left(\mathrm{mg} \mathrm{L}^{-1}\right)\end{array}$ & $\begin{array}{c}\mathrm{HCO}_{3}^{-} \\
\left(\mathrm{mg} \mathrm{L}^{-1}\right)\end{array}$ & $\begin{array}{r}\mathrm{K}^{+} \\
\left(\mathrm{mg} \mathrm{L}^{-1}\right)\end{array}$ & $\begin{array}{r}\mathrm{Mg}^{2+} \\
\left(\mathrm{mg} \mathrm{L}^{-1}\right)\end{array}$ & $\begin{array}{r}\mathrm{Na}^{+} \\
\left(\mathrm{mg} \mathrm{L}^{-1}\right)\end{array}$ & $\begin{array}{r}\mathrm{Si} \\
\left(\mathrm{mg} \mathrm{L}^{-1}\right)\end{array}$ & $\begin{array}{r}\mathrm{SO}_{4}^{2-} \\
\left(\mathrm{mg} \mathrm{L}^{-1}\right)\end{array}$ \\
\hline \multicolumn{16}{|c|}{ Group A } \\
\hline 2272 & $18 \mathrm{Feb} 2011$ & 9.36 & 5.89 & -0.22 & 7440 & 4.7 & 362.6 & 3292 & 0 & 53.1 & 10.1 & 263.0 & 1560 & 32.2 & 700.0 \\
\hline 2273 & $18 \mathrm{Feb} 2011$ & 3.46 & 6.25 & -4.86 & 7190 & 4.7 & 213.0 & 3110 & 0 & 85.8 & 9.2 & 266.9 & 1430 & 31.0 & 728.2 \\
\hline 2275 & 17 Feb 2011 & 11.86 & 4.94 & -5.19 & 5180 & 5.5 & 73.4 & 2231 & 0 & 6.8 & 9.3 & 148.9 & 1100 & 38.1 & 373.3 \\
\hline 2276 & $17 \mathrm{Feb} 2011$ & 1.79 & 6.51 & -3.01 & 4280 & 4.1 & 115.2 & 1595 & 0 & 97.6 & 3.6 & 102.3 & 855 & 14.5 & 380.4 \\
\hline 2278 a & 24 Nov 2010 & 18.72 & 4.38 & -1.16 & 3400 & 4.7 & 21.9 & 1179 & 0.2 & 0.3 & 2.1 & 50.4 & 665 & 38.5 & 85.1 \\
\hline $2278 b$ & 15 Feb 2011 & 18.72 & 4.49 & 0.70 & 4630 & 4.9 & 24.2 & 1190 & 0 & 3.1 & 2.3 & 56.0 & 745 & 40.1 & 198.7 \\
\hline 2280 & 24 Nov 2010 & 23.66 & 6.04 & -2.29 & 6990 & 6.8 & 139.4 & 2990 & 10.4 & 11.8 & 24 & 248.7 & 1340 & 23.4 & 294.8 \\
\hline 2282 & 16 Feb 2011 & 23.81 & 5.19 & 5.78 & 1060 & 6.4 & 29.5 & 329 & 0 & 6.3 & 3.5 & 19.4 & 200 & 32.2 & 56.6 \\
\hline 2283 & 23 Nov 2010 & 14.78 & 4.50 & 3.62 & 5260 & 6.5 & 50.8 & 2064 & 0 & $0^{*}$ & 6.0 & 173.6 & 1125 & 43.3 & 153.1 \\
\hline 2284 & 17 Feb 2011 & 5.38 & 4.25 & -2.23 & 8340 & 5.1 & 139.0 & 3909 & 0 & $0^{*}$ & 8.7 & 385.3 & 1910 & 43.3 & 821.6 \\
\hline 2285 & 25 Aug 2010 & 8.01 & 4.67 & 0.48 & 10660 & 6.9 & 111.1 & 3537 & 0 & 4.6 & 19.5 & 396.7 & 1560 & 34.1 & 272.7 \\
\hline 2289 & 23 Aug 2010 & 27.0 & 5.47 & 0.90 & 8740 & 3.77 & 178.9 & 2833 & 5.6 & 18.6 & 9.0 & 277.0 & 1260 & 25.7 & 251.2 \\
\hline 2290 & 23 Aug 2010 & 14.0 & 5.64 & 3.06 & 9090 & 5.3 & 181.5 & 2788 & 9.4 & 14.8 & 9.4 & 259.8 & 1340 & 25.2 & 249.9 \\
\hline 2291 & 24 Aug 2010 & 34.9 & 4.77 & 0.79 & 4140 & 8.7 & 32.4 & 1114 & 0 & 2.3 & 8.4 & 62.7 & 635 & 35.0 & 125.4 \\
\hline 2292 & 23 Aug 2010 & 27.7 & 6.43 & 1.26 & 5130 & 1.05 & 320.9 & 1490 & 5.5 & 134.5 & 8.2 & 85.1 & 565 & 22.9 & 124.5 \\
\hline 2293 & 23 Nov 2010 & 12.5 & 5.74 & -1.80 & 3860 & 7.2 & 47.0 & 1357 & 0 & 11.5 & 3.5 & 76.9 & 725 & 29.8 & 157.9 \\
\hline 2294 & 25 Aug 2010 & 29.0 & 5.63 & -0.94 & 9100 & 8.5 & 107.3 & 2891 & 0.1 & 20.8 & 26.0 & 386.4 & 1140 & 31.9 & 341.3 \\
\hline 2295 & 23 Nov 2010 & 23.8 & 5.93 & -2.34 & 7190 & 2.7 & 138.0 & 2732 & 4.8 & 31.5 & 11.3 & 222.6 & 1210 & 27.1 & 211.2 \\
\hline 2296 & 24 Nov 2010 & 6.275 & 5.93 & 0.47 & 7300 & 5.2 & 81.0 & 2553 & 0 & 25.0 & 0.8 & 138.5 & 1420 & 33.4 & 197.1 \\
\hline 2297 & 9 Aug 2011 & 51.35 & 6.45 & -9.63 & 7450 & 2.59 & 173.2 & 3494 & 3.4 & 386.5 & 70.0 & 322.7 & 1680 & 14.1 & 1304.0 \\
\hline \multicolumn{16}{|c|}{ Group B } \\
\hline 2277 & $16 \mathrm{Feb} 2011$ & 18.46 & 5.38 & -19.91 & 150 & 3.05 & 0.8 & 28 & 0.2 & 10.9 & 0.5 & 2.5 & 29 & 11.9 & 62.6 \\
\hline 2279 & 16 Feb 2011 & 24.39 & 5.65 & -10.18 & 220 & 5.9 & 2.6 & 38 & 0 & 15.1 & 2.6 & 6.3 & 31.7 & 7.5 & 59.6 \\
\hline 2281 & 16 Feb 2011 & 7.76 & 4.62 & -5.90 & 1890 & 7.1 & 12.4 & 668 & 0 & 2.0 & 2.3 & 28.5 & 428 & 41.5 & 260.2 \\
\hline \multicolumn{16}{|c|}{ Surface water } \\
\hline Dwyer's Ck. & 23 Aug 2010 & 0 & 6.16 & -0.41 & 3320 & 10.5 & 66.3 & 975 & 0 & 16.5 & 1.8 & 87.9 & 447.5 & 2.6 & 120.8 \\
\hline $\begin{array}{l}\text { Lambing } \\
\text { Hut Ck. }\end{array}$ & 6 Jun 2011 & 0 & 6.00 & -1.03 & 8680 & 9.9 & 242.7 & 3416 & 0 & 24.0 & 5.9 & 286.3 & 1700 & 12.8 & 726.5 \\
\hline
\end{tabular}


Table 2. Groundwater dates. Samples with ${ }^{14} \mathrm{C}$ activity $>100 \mathrm{pMC}$ are younger than 1950 . Samples with measureable tritium contain groundwater $<50 \mathrm{yr}$ old, in some cases mixed with older groundwater $(\mathrm{pMC}<100)$.

\begin{tabular}{|c|c|c|c|c|c|c|}
\hline Sample ID & $\mathrm{a}^{14} \mathrm{C}(\mathrm{pMC})$ & $1 \sigma-$ error & Radiocarbon age & $1 \sigma-$ error & Activity of ${ }^{3} \mathrm{H}\left(\mathrm{Bq} \mathrm{kg}^{-1}\right)$ & $1 \sigma-$ error \\
\hline \multicolumn{7}{|c|}{ Group A } \\
\hline 2272 & 81.26 & \pm 0.28 & 1665 & \pm 30 & $\mathrm{BD}$ & \\
\hline 2273 & 77.43 & \pm 0.28 & 2055 & \pm 30 & & \\
\hline 2275 & 89.01 & \pm 0.36 & 935 & \pm 35 & & \\
\hline 2276 & 93.11 & \pm 0.31 & 575 & \pm 30 & $\mathrm{BD}$ & \\
\hline $2278 \mathrm{a}$ & 92.27 & \pm 0.93 & 650 & \pm 90 & $\mathrm{BD}$ & \\
\hline \multicolumn{7}{|l|}{$2278 b$} \\
\hline 2280 & 98.56 & \pm 0.33 & 115 & \pm 30 & 0.148 & \pm 0.01 \\
\hline 2282 & 94.81 & \pm 0.32 & 430 & \pm 30 & 0.072 & \pm 0.006 \\
\hline 2283 & 91.85 & \pm 0.34 & 685 & \pm 30 & BD & \\
\hline 2284 & 90.7 & \pm 0.34 & 785 & \pm 30 & & \\
\hline 2285 & * & * & * & * & $\mathrm{BD}$ & \\
\hline 2289 & 40.15 & \pm 0.24 & 7330 & \pm 50 & & \\
\hline 2290 & 41.93 & \pm 0.23 & 6980 & \pm 45 & & \\
\hline 2291 & 94.97 & \pm 0.31 & 415 & \pm 30 & 0.047 & \pm 0.005 \\
\hline 2292 & 7.53 & \pm 0.08 & 20770 & \pm 90 & $\mathrm{BD}$ & \\
\hline 2293 & 91.39 & \pm 0.32 & 725 & \pm 30 & 0.087 & \pm 0.007 \\
\hline 2294 & 77.38 & \pm 0.28 & 2060 & \pm 30 & BD & \\
\hline 2295 & 64.36 & \pm 0.24 & 3540 & \pm 30 & BD & \\
\hline 2296 & 95.78 & \pm 0.28 & 345 & \pm 25 & 0.133 & \pm 0.011 \\
\hline 2297 & 49.45 & \pm 0.20 & 5655 & \pm 35 & 0.0354 & \pm 0.005 \\
\hline \multicolumn{7}{|c|}{ Group B } \\
\hline 2277 & 104.52 & \pm 0.43 & Modern & & 0.339 & \pm 0.015 \\
\hline 2279 & 104.93 & \pm 0.35 & Modern & & 0.304 & \pm 0.014 \\
\hline 2281 & 91.77 & \pm 1.03 & 690 & \pm 100 & 0.094 & \pm 0.007 \\
\hline
\end{tabular}

* $\mathrm{CO}_{2}$ too low; $\mathrm{BD}=$ below detectable limit.

showed no significant compositional changes over this time, which included a shift from drought to wetter conditions. Six other bores (2285, 2289, 2290, 2291, 2292 and 2294) were also sampled twice, 10 months apart for field parameters only, and showed no significant change either. Groundwater bores were sampled after first removing three holding volumes to ensure representative water samples were obtained (USEPA, 1999). Temperature, $\mathrm{pH}$, dissolved oxygen and electrical conductivity were all measured in the field, at the time of sampling.

The focus of this study is on the long term groundwater evolution, with no intention of reporting a "present-day" weathering mass balance which would require a much higher resolution sampling of the surface water (Velbel and Price, 2007).

\subsubsection{Chemical analysis}

Sub-samples for cations were filtered through $0.45 \mu \mathrm{m}$ filter paper and acidified using $\mathrm{HNO}_{3} . \mathrm{Na}^{+}$and $\mathrm{K}^{+}$were analysed on a flame photometer, and $\mathrm{Ca}^{2+}$ and $\mathrm{Mg}^{2+}$ were analysed using atomic absorption spectroscopy. Subsamples for anions were filtered with $0.45 \mu \mathrm{m}$ filter paper, but not acidified. $\mathrm{HCO}_{3}^{-}$was manually repeat-titrated to a $\mathrm{pH}$ of 4.5 using $\mathrm{HCl}$ standardised to $\mathrm{NaCO}_{3}$. Si was analysed using inductively coupled plasma optical emission spectroscopy, $\mathrm{Cl}^{-}$ was analysed using ion chromatography, and $\mathrm{SO}_{4}^{2-}$ was analysed using both these methods. Each of these analyses was completed at La Trobe University, Melbourne. All charge balance errors were within $\pm 10 \%$, except for one sample in Group B $(-19 \%$, most likely due to an underestimation of $\mathrm{Ca}^{2+}$ ), which is very dilute (Table 1), and so this level of accuracy is acceptable (Hem, 1985).

\subsection{2 ${ }^{14} \mathrm{C}$ analysis}

Radiocarbon dating was carried out at the Australian Nuclear Science and Technology Organisation (ANSTO) in Sydney, where dissolved inorganic carbon was extracted from the water samples by addition of phosphoric acid and sparging with $\mathrm{He} . \mathrm{CO}_{2}$ was collected cryogenically then converted to graphite by reduction with hydrogen over an iron catalyst at $600^{\circ} \mathrm{C}$ (Hua et al., 2001). The graphite target was measured on the STAR or ANTARES accelerator, with all 
Table 3. Rainfall composition $\left(\mathrm{mol} \mathrm{L}^{-1} \times 10^{5}\right)$.

\begin{tabular}{lrrrrrrrr}
\hline Sample ID & $\mathrm{Ca}^{2+}$ & $\mathrm{Cl}^{-}$ & $\mathrm{HCO}_{3}^{-}$ & $\mathrm{K}^{+}$ & $\mathrm{Mg}^{2+}$ & $\mathrm{Na}^{+}$ & $\mathrm{Si}$ & $\mathrm{SO}_{4}^{2-}$ \\
\hline Rainfall: Cavendish & 1.50 & 12.0 & 4.00 & 0.50 & 1.50 & 12.0 & $\mathrm{ND}$ & $\mathrm{ND}$ \\
Rainfall: Hamilton & 2.45 & 12.8 & $\mathrm{UR}$ & 3.09 & 2.41 & 10.9 & 0.08 & 2.52 \\
Rainfall: Horsham & 3.44 & 9.39 & $\mathrm{UR}$ & 0.64 & 1.18 & 9.52 & $\mathrm{ND}$ & 1.55 \\
Median Rainfall & 2.45 & 12.0 & 4.00 & 0.64 & 1.50 & 10.9 & 0.08 & 2.03 \\
\hline
\end{tabular}

$\mathrm{ND}=$ not determined $; \mathrm{UR}=$ unreliable data.

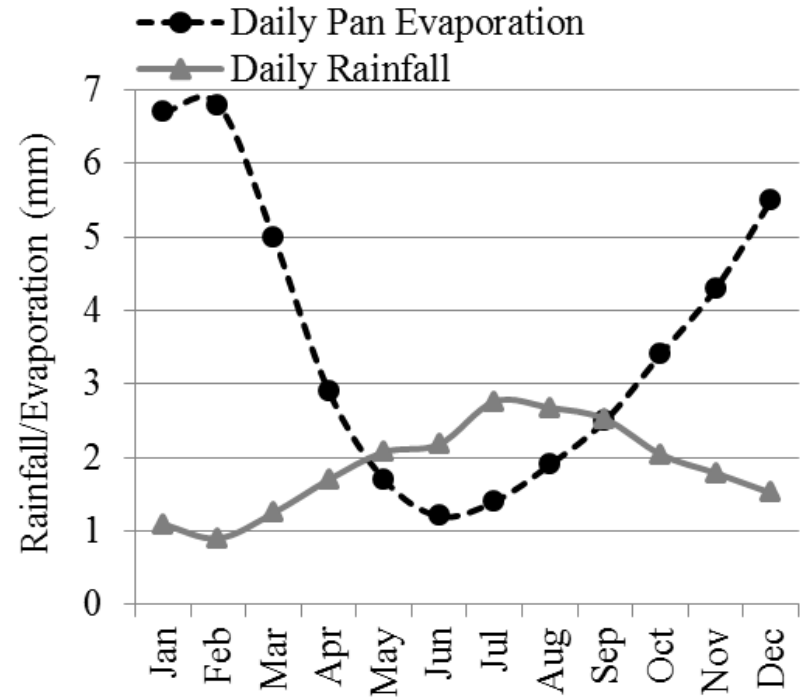

Figure 2. Average daily rainfall and potential evaporation for the study region, based on data from 1965-2000, Hamilton, Victoria, Bureau of Meteorology.

measurements normalised against the oxalic acid (HOXI) international standard. For each sample ${ }^{14} \mathrm{C}$ concentration and/or radiocarbon age was determined after corrections for AMS (Accelerator Mass Spectrometry) machine background, procedural blank and isotopic fractionation using the $\delta^{13} \mathrm{C}$ of the graphite which was obtained by analysis using EA-IRMS (Elemental Analysis - Isotope Ratio Mass Spectrometry) (Fink et al., 2004). Radiocarbon ages are uncalibrated ages (Table 2). Samples with pMC values $>100$ are considered modern, i.e. younger than 1950 (Clark and Fritz, 1997). A correction for dead carbon was not required due to the absence of carbonates in the granite and overlying regolith (based on XRD (X-Ray Diffraction) analyses), and the limited effects of other processes potentially affecting the ${ }^{14} \mathrm{C}$ activity in this region (Cartwright, 2010).

\subsubsection{Tritium analysis}

Samples were analysed for tritium at ANSTO by distillation, electrolytic enrichment and finally counting using the liquid scintillation counting technique. Samples with measureable tritium values contain modern groundwater, i.e. recharged in

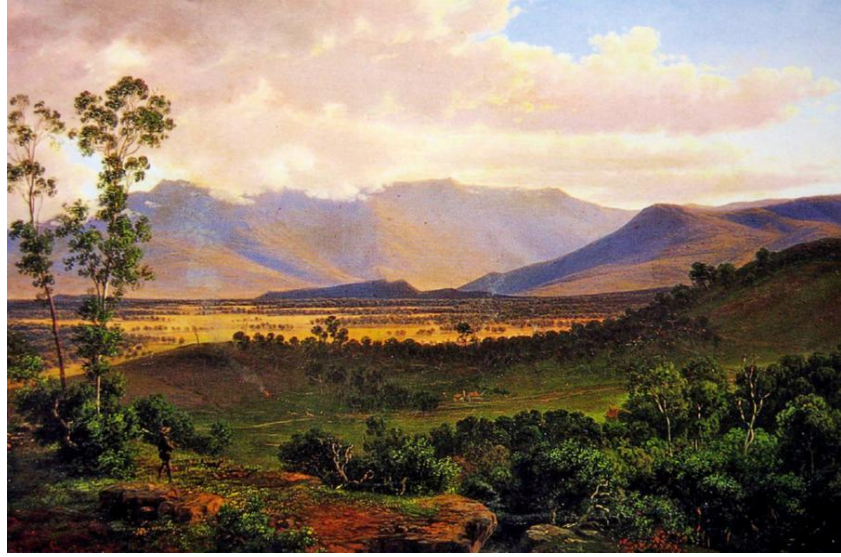

Figure 3. Painting of Victoria Valley prior to land clearance (Eugene vo Guérard, 1866; courtesy of Sotheby's Australia).

the past $50 \mathrm{yr}$ (Clark and Fritz, 1997). Some of these samples also have $\mathrm{pMC}<100$, indicating that they are mixtures of older and younger water. Using data from Adelaide, Cape Grim and Melbourne for atmospheric tritium present in rainfall and the decay curve of tritium (half-life of $12.32 \mathrm{yr}$ ), the ages of the modern groundwater components can be estimated, e.g. sample 2297 is most likely to have received some recharge in 1960 or earlier (Fig. 4). However, the age of most samples is poorly constrained, e.g. sample 2281 has a much broader age window, from 1975-1995 or during 1960 and earlier (Fig. 4).

\subsection{Geochemical mass balance}

Geochemical mass balances are a popular method for determining the source of solutes in groundwater and surface water, particularly the contribution from weathering (Garrels and Mackenzie, 1967; Velbel and Price, 2007). In a typical geochemical mass balance, the local rainfall composition is subtracted from the groundwater composition, and the remaining element concentrations present are assigned to processes taking place within the system, particularly mineral weathering reactions.

The method was adapted for southwest Victoria by normalising the concentrations of all the ions in the groundwater and surface water to rainfall $\mathrm{Cl}^{-}$, to remove the effects 


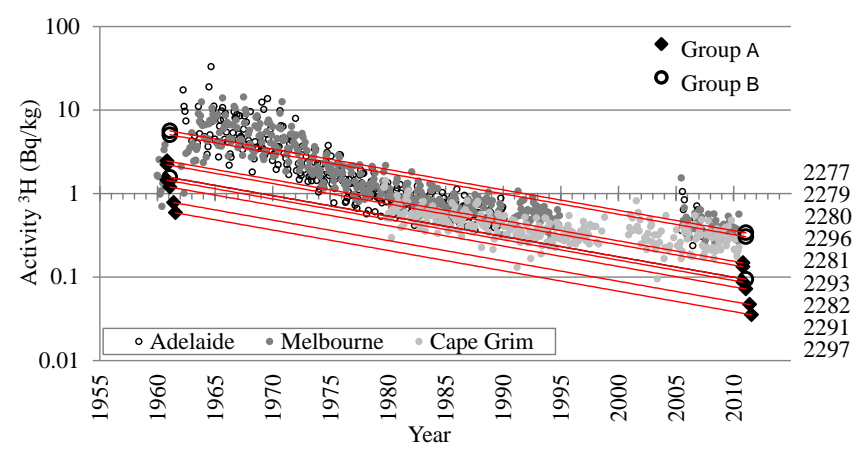

Figure 4. Tritium decay curves for the nine samples with detectable tritium levels (Table 2); each curve is calculated for 50 years of decay. The atmospheric tritium values are shown also to indicate possible recharge times; unpublished rainfall data from ANSTO. The precision of the tritium dates varies; sample 2297 was recharged in 1960 or earlier, whereas sample 2281 was recharged from 19751995 or during 1960 and earlier.

of evapotranspiration (Moulton et al., 2000). While this step is commonly omitted in high rainfall, Northern Hemisphere studies of groundwater and surface water composition (Garrels and Mackenzie, 1967; Taylor and Velbel, 1991; Velbel and Price, 2007; White et al., 2002), it is important in the southeast Australian setting where groundwater solutes are strongly concentrated by evapotranspiration, which is typically higher than rainfall for much of the year (Fig. 2; Bennetts et al., 2006; Herczeg et al., 2001). $\mathrm{Cl}^{-}$is assumed to be conservative at the study site over the time period of groundwater recharge $(\sim 20000 \mathrm{yr})$, with rainfall the dominant $\mathrm{Cl}^{-}$ source; $\mathrm{Cl}^{-} / \mathrm{Br}^{-}$ratios from nearby studies rule out significant input from wind-blown halite deposition (Bennetts et al., 2006; Edwards and Webb, 2009; Raiber et al., 2009).

To calculate the mass balance, the local rainfall chemical composition is subtracted from the normalised groundwater and surface water compositions, and the net values remaining can then be used to stoichiometrically balance the expected water-mineral chemical reactions. The groundwater values used in the mass balance are median values of each of the two groups of samples identified in this study (see Sect. 4.1; Fig. 5).

The rainfall composition used in this study was the median local rainfall chemistry from three nearby sites: Cavendish (1954-1955, lacks $\mathrm{Si}$ and $\mathrm{SO}_{4}^{2-}$ data; Hutton and Leslie, 1958), Hamilton (2003-2004, unreliable $\mathrm{HCO}_{3}^{-}$data; Bormann, 2004), and Horsham (2007-2009, $\mathrm{HCO}_{3}^{-}$by charge balance only; Nation, 2009) (Table 3; Fig. 1). The median of these three data sets takes into account the natural variability of rainfall chemistry during different climatic conditions, including wet (1954-1955) and dry (2003-2004 and 20072009) years. For each station, the entire rainfall for each year was collected using a standard rainfall gauge, which by its design (an open funnel) automatically collects both rainfall and dry deposition. Because groundwater in the study area is

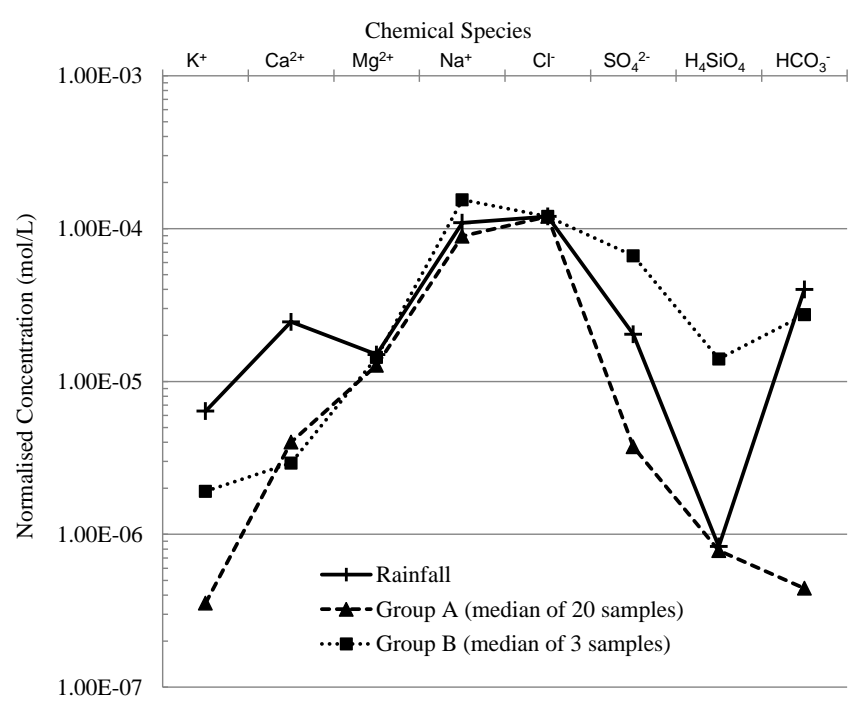

Figure 5. Schoeller plot of sampled waters normalised to local rainfall $\mathrm{Cl}^{-}$(see Sect. 4.2).

up to $20000 \mathrm{yr}$ old (Table 2), climate variations over this time period will have affected the rainfall composition, which was probably more concentrated during the arid phase at the Last Glacial Maximum $(\sim 20 \mathrm{ka})$, when there is evidence of dune mobility in southeastern Australia (e.g. Gardner et al., 2006). However the ion/chloride ratios of rainfall were probably little changed by the increase in aridity; the distance from the coast, which is the dominant influence on rainfall composition in this area (Hutton, 1976), did not increase significantly during the fall in sea level at the Last Glacial Maximum, as the continental shelf is relatively narrow. Because the mass balance involves normalising the concentrations of all ions in groundwater and surface water to rainfall $\mathrm{Cl}^{-}$, any change in rainfall composition that does not significantly affect the ion/chloride ratios will not alter the results of the mass balance calculations.

\subsubsection{Isocon diagram and element mobility}

During granite weathering, feldspars and mafic minerals are altered to clays with a concomitant loss of soluble ions into groundwater. The overall chemical change can be quantified by comparing the unaltered granite composition with that of the in situ overlying weathered granite regolith using an isocon plot (Grant, 1986). In this method, the changes in element concentrations as fresh rock is weathered to regolith are determined by plotting the weight percents of all elements in both materials against each other. Immobile elements plot along a straight line (the isocon), those that are lost as the fresh rock weathers plot below the isocon, and those that become enriched, or more concentrated during weathering, plot above the isocon (Grant, 1986). $\mathrm{Zr}$ is generally immobile during weathering so isocons are typically defined using this element (Grant, 1986; Webb and Golding, 1998). 


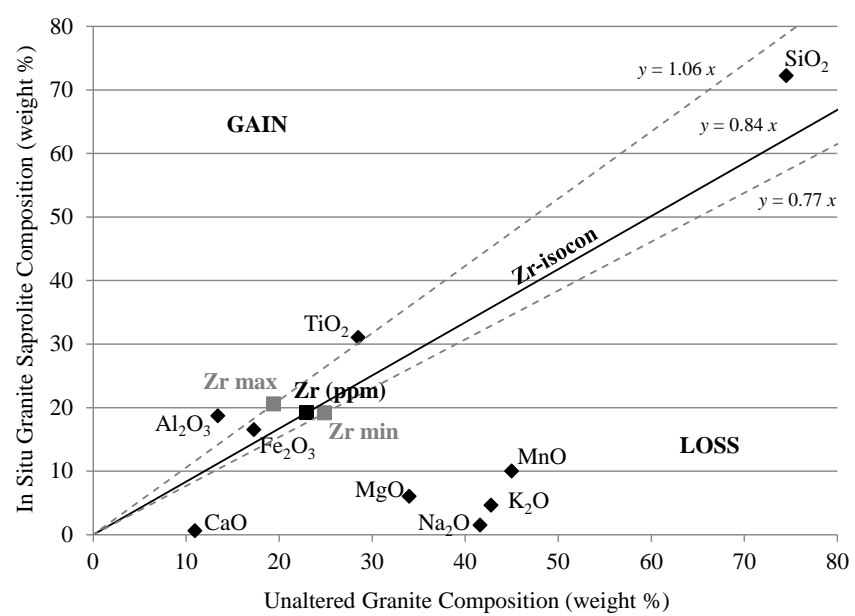

Figure 6. Comparison of element concentrations of the in situ granite saprolite (median of 3 analyses) and the unaltered granite (Hergt et al., 2007) from the study site (determined by X-ray fluorescence (XRF) analysis). $\mathrm{Zr}$ (as ppm) is assumed to be immobile and an isocon (Grant, 1986; Webb and Golding, 1998) is defined from the origin through this point. Above this line the granite saprolite is enriched in that element, below the line it is depleted. Minimum and maximum isocons are defined by the equivalent $\mathrm{Zr}$ ratios from both sets of analyses. In order to better show some elements visually on this graph both values were multiplied by 10,100 or 1000 . As these are ratios, so long as both values have the same multiplication applied to them, the result is not affected.

The slope of the isocon defines the mass change during alteration; the relative enrichment or depletion of mobile elements can then be calculated from the following equation:

$\%$ change in composition $=$

$\frac{C_{x}[\text { weathered regolith }]-A \bullet C_{x}[\text { fresh rock }]}{A \bullet C_{x}[\text { fresh rock }]} \bullet 100$,

where $A$ is the slope of the isocon $\left(\mathrm{Zr}_{\text {[weathered regolith] }} / \mathrm{Zr}_{\text {[freshrock] }} ; \mathrm{Zr}\right.$ is the concentration of Zirconium), and $C_{x}$ is the concentration in wt $\%$ of element $x$ in either the weathered regolith or the fresh rock (Grant, 1986). The change in composition calculated from Eq. (1) is exactly equivalent to the mass transfer coefficient of Brimhall et al. (1991), and is the negative of the chemical depletion fractions (CDF) as defined by Riebe et al. (2003):

$$
\begin{aligned}
& \mathrm{CDF}_{x}= \\
& \left(1-\frac{C_{x}[\text { weathered regolith }]}{C_{x}[\text { fresh rock }]} \frac{\mathrm{Zr}[\text { fresh rock }]}{\mathrm{Zr}[\text { weathered regolith }]}\right) .
\end{aligned}
$$

Those elements that have been lost from the system during the weathering of the fresh rock to regolith can be clearly identified, and are assumed to enrich the groundwater and surface water as they are exported (Garrels and Mackenzie, 1967). In the present study, the isocon was calculated using the composition of the fresh granite taken from Hergt
Table 4. Major element (wt\%) composition of weathered and unaltered granite from the study site.

\begin{tabular}{lrrr}
\hline Species & Weathered $^{\mathrm{a}}$ & Unweathered $^{\mathrm{b}}$ & $\begin{array}{r}\text { \% change in } \\
\text { composition }\end{array}$ \\
\hline $\mathrm{Zr}(\mathrm{ppm})$ & 191.9 & 229.5 & \\
$\mathrm{SiO} 2(\%)$ & 72.2 & 74.53 & 15.85 \\
$\mathrm{TiO} 2(\%)$ & 0.31 & 0.285 & 30.08 \\
$\mathrm{~A} 2 \mathrm{O} 3(\%)$ & 18.69 & 13.415 & 66.61 \\
$\mathrm{Fe} 2 \mathrm{O} 3(\%)$ & 1.65 & 1.73 & 14.06 \\
$\mathrm{MnO}(\%)$ & 0.01 & 0.045 & -73.42 \\
$\mathrm{MgO}(\%)$ & 0.06 & 0.34 & -78.90 \\
$\mathrm{CaO}(\%)$ & 0.06 & 1.095 & -93.45 \\
$\mathrm{Na} 2 \mathrm{O}(\%)$ & 0.15 & 4.16 & -95.69 \\
$\mathrm{~K} 2 \mathrm{O}(\%)$ & 0.46 & 4.28 & -87.15 \\
$\mathrm{P} 2 \mathrm{O} 5(\%)$ & 0.02 & 0.05 & -52.16 \\
$\mathrm{LOI}(\%)$ & 7.23 & & \\
\hline a Median of three analyses; ${ }^{\mathrm{b}}$ from Hergt et al. (2007) &
\end{tabular}

et al. (2007), and the composition of the weathered granite in the overlying regolith obtained from XRF analyses (Table 4; Fig. 6).

\subsubsection{X-ray fluorescence (XRF) and X-ray diffraction (XRD)}

The bulk chemical composition of weathered granite samples from bore 2281 at depths of 6,18 and $38 \mathrm{~m}$ was determined by XRF using $0.7500 \pm 0.0001 \mathrm{~g}$ of sample mixed with $6.7500 \pm 0.0001 \mathrm{~g}$ of $66: 34$ lithium tetraborate : lithium metaborate flux (oven-dried at $400^{\circ} \mathrm{C}$ for $2 \mathrm{~h}$ ) and fused at $1050^{\circ} \mathrm{C}$ into a glass button using an automated fusion machine. Glass buttons were analysed using a Siemens SRS 303 AS Wavelength Dispersive XRF spectrometer. Elements were reported as wt $\%$ oxides (Table 4).

XRD analysis was performed on the same samples (dried and milled to $\sim 60 \mu \mathrm{m}$ ) from $4-70^{\circ}$ for $90 \mathrm{~min}$, using a Siemens D5000 X-ray Diffractometer.

\section{Results and discussion}

\subsection{Geochemical mass balance I - Group A groundwater and surface water samples}

For the majority of groundwater samples (20), once the rainfall had been subtracted from the normalised concentrations, the remaining concentrations of all the major chemical species were negative (Table 5); these samples are termed Group A. These negative values mean that there are no remaining element concentrations to assign to water-mineral interactions once rainfall inputs have been taken into account, and therefore the mass balance cannot be taken past this step.

The groundwater samples show a wide variety of ages, from modern to $20000 \mathrm{yr}$ old, but there is no clear relationship between aquifer residence time and cation 
Table 5. Subtraction of rainfall input from groundwater composition.

\begin{tabular}{|c|c|c|c|c|c|c|c|c|}
\hline Group A (20 samples) & $\mathrm{K}^{+}$ & $\mathrm{Ca}^{2+}$ & $\mathrm{Mg}^{2+}$ & $\mathrm{Na}^{+}$ & $\mathrm{Cl}^{-}$ & $\mathrm{SO}_{4}^{2-}$ & $\mathrm{H}_{4} \mathrm{SiO}_{4}$ & $\mathrm{HCO}_{3}^{-}$ \\
\hline $\begin{array}{l}\text { Median groundwater } \\
\text { concentrations }\left(\mathrm{mol} \mathrm{L}^{-1} \times 10^{5}\right)\end{array}$ & 22.2 & 258 & 687 & 4960 & 7230 & 175 & 53.3 & 22.6 \\
\hline $\begin{array}{l}\text { Median normalised } \\
\text { groundwater concentration } \\
\left(\mathrm{mol} \mathrm{L}^{-1} \times 10^{5}\right)\end{array}$ & 0.04 & 0.40 & 1.28 & 8.91 & 12.00 & 0.37 & 0.08 & 0.04 \\
\hline Median rainfall $\left(\mathrm{mol} \mathrm{L}^{-1} \times 10^{5}\right)$ & 0.64 & 2.45 & 1.50 & 10.92 & 12.00 & 2.03 & 0.08 & 4.00 \\
\hline $\begin{array}{l}\text { Net species addition/depletion } \\
\text { after rainfall subtraction } \\
\left(\mathrm{mol} \mathrm{L}^{-1} \times 10^{5}\right)\end{array}$ & -0.60 & -2.05 & -0.22 & -2.01 & 0 & -1.66 & 0 & -3.96 \\
\hline Group B (3 samples) & $\mathrm{K}^{+}$ & $\mathrm{Ca}^{2+}$ & $\mathrm{Mg}^{2+}$ & $\mathrm{Na}^{+}$ & $\mathrm{Cl}^{-}$ & $\mathrm{SO}_{4}^{2-}$ & $\mathrm{H}_{4} \mathrm{SiO}_{4}$ & $\mathrm{HCO}_{3}^{-}$ \\
\hline $\begin{array}{l}\text { Median groundwater } \\
\text { concentrations }\left(\mathrm{mol} \mathrm{L}^{-1} \times 10^{5}\right)\end{array}$ & 5.84 & 6.09 & 23.8 & 138 & 107 & 63.9 & 19.8 & 18.2 \\
\hline $\begin{array}{l}\text { Median normalised } \\
\text { groundwater concentration } \\
\left(\mathrm{mol} \mathrm{L}^{-1} \times 10^{5}\right)\end{array}$ & 0.19 & 0.29 & 1.44 & 15.44 & 12.00 & 6.64 & 1.40 & 2.73 \\
\hline Median rainfall $\left(\mathrm{mol} \mathrm{L}^{-1} \times 10^{5}\right)$ & 0.64 & 2.45 & 1.50 & 10.92 & 12.00 & 2.03 & 0.08 & 4.00 \\
\hline $\begin{array}{l}\text { Net species addition/depletion } \\
\text { after rainfall subtraction } \\
\left(\mathrm{mol} \mathrm{L}^{-1} \times 10^{5}\right)\end{array}$ & -0.45 & -2.16 & -0.06 & 4.52 & 0 & 4.61 & 1.32 & -1.27 \\
\hline
\end{tabular}

Table 6. Subtraction of rainfall input from surface water composition.

\begin{tabular}{|c|c|c|c|c|c|c|c|c|}
\hline & $\mathrm{K}^{+}$ & $\mathrm{Ca}^{2+}$ & $\mathrm{Mg}^{2+}$ & $\mathrm{Na}^{+}$ & $\mathrm{Cl}^{-}$ & $\mathrm{SO}_{4}^{2-}$ & $\mathrm{H}_{4} \mathrm{SiO}_{4}$ & $\mathrm{HCO}_{3}^{-}$ \\
\hline $\begin{array}{l}\text { Dwyer's Ck. composition } \\
\left(\mathrm{mol} \mathrm{L}^{-1} \times 10^{5}\right)\end{array}$ & 4.60 & 158 & 346 & 1950 & 2760 & 98.6 & 4.28 & 26.2 \\
\hline $\begin{array}{l}\text { Normalised Dwyer's Ck. } \\
\text { composition }\left(\mathrm{mol} \mathrm{L}^{-1} \times 10^{5}\right)\end{array}$ & 0.02 & 0.69 & 1.51 & 8.47 & 12.00 & 0.43 & 0.02 & 0.11 \\
\hline Median rainfall $\left(\mathrm{mol} \mathrm{L}^{-1} \times 10^{5}\right)$ & 0.64 & 2.45 & 1.50 & 10.92 & 12.00 & 2.03 & 0.08 & 4.00 \\
\hline \multirow{2}{*}{$\begin{array}{l}\text { Net species addition/depletion } \\
\text { after subtraction of rainfall } \\
\left(\mathrm{mol} \mathrm{L}^{-1} \times 10^{5}\right)\end{array}$} & -0.62 & -1.76 & -0.01 & -2.45 & 0 & -1.60 & -0.06 & -3.89 \\
\hline & $\mathrm{K}^{+}$ & $\mathrm{Ca}^{2+}$ & $\mathrm{Mg}^{2+}$ & $\mathrm{Na}^{+}$ & $\mathrm{Cl}^{-}$ & $\mathrm{SO}_{4}^{2-}$ & $\mathrm{H}_{4} \mathrm{SiO}_{4}$ & $\mathrm{HCO}_{3}^{-}$ \\
\hline $\begin{array}{l}\text { Lambing Hut Ck. composition } \\
\left(\mathrm{mol} \mathrm{L}^{-1} \times 10^{5}\right)\end{array}$ & 15.0 & 546 & 1060 & 7380 & 9700 & 518 & 21.5 & 44.3 \\
\hline $\begin{array}{l}\text { Normalised Lambing Hut Ck. } \\
\text { composition }\left(\mathrm{mol} \mathrm{L}^{-1} \times 10^{5}\right)\end{array}$ & 0.02 & 0.68 & 1.32 & 9.13 & 12.00 & 0.64 & 0.03 & 0.05 \\
\hline Median rainfall $\left(\mathrm{mol} \mathrm{L}^{-1} \times 10^{5}\right)$ & 0.64 & 2.45 & 1.50 & 10.92 & 12.00 & 2.03 & 0.08 & 4.00 \\
\hline $\begin{array}{l}\text { Net species addition/depletion } \\
\text { after subtraction of rainfall } \\
\left(\mathrm{mol} \mathrm{L}^{-1} \times 10^{5}\right)\end{array}$ & -0.62 & -1.77 & -0.18 & -1.79 & 0 & -1.39 & -0.05 & -3.95 \\
\hline
\end{tabular}

concentrations (Fig. 7a and b). The varying times for groundwater to interact with the aquifer rock have not resulted in an increase in cation concentrations with groundwater age; most of the modern groundwater (containing tritium: 0.035$0.399 \mathrm{Bqkg}^{-1}$ ) shows a similar range of cation depletion to much older samples. There is also no relationship be- tween groundwater sampling depth and cation concentrations (Fig. 7c).

Surface water in both creeks in the study area, like the Group A groundwater, is depleted in all species with respect to rainfall (Table 6), but because we don't know the rate of elemental uptake by biomass, and the surface water was not regularly sampled, the stream compositions cannot be used 
Table 7. Mass balance calculations to show influence of pyrite oxidation and plagioclase weathering on Group B groundwater composition.

\begin{tabular}{|c|c|c|c|c|c|c|c|c|}
\hline Group B (3 samples) & $\mathrm{K}^{+}$ & $\mathrm{Ca}^{2+}$ & $\mathrm{Mg}^{2+}$ & $\mathrm{Na}^{+}$ & $\mathrm{Cl}^{-}$ & $\mathrm{SO}_{4}^{2-}$ & $\mathrm{H}_{4} \mathrm{SiO}_{4}$ & $\mathrm{HCO}_{3}^{-}$ \\
\hline $\begin{array}{l}\text { Net species addition/depletion } \\
\text { after rainfall subtraction } \\
\left(\mathrm{mol} \mathrm{L}^{-1} \times 10^{5}\right)\end{array}$ & -0.45 & -2.16 & -0.06 & 4.52 & 0 & 4.61 & 1.32 & -1.27 \\
\hline $\begin{array}{l}\text { Release of ions by pyrite and } \\
\text { plagioclase weathering } \\
\left(\mathrm{mol} \mathrm{L}^{-1} \times 10^{5}\right)\end{array}$ & 0 & 1.43 & 0 & 4.52 & 0 & 4.61 & 9.04 & 0 \\
\hline $\begin{array}{l}\text { Net species addition/depletion } \\
\text { after subtraction of ions } \\
\text { released by pyrite and } \\
\text { plagioclase weathering } \\
\left(\mathrm{mol} \mathrm{L}^{-1} \times 10^{5}\right)\end{array}$ & -0.45 & -3.59 & -0.06 & 0 & 0 & 0 & -7.72 & -1.27 \\
\hline
\end{tabular}

Table 8. Saturation indices for all the groundwater and surface water samples used in this study.

\begin{tabular}{|c|c|c|c|c|}
\hline Sample ID & SI: Calcite & SI: Gypsum & SI: Aragonite & SI: Halite \\
\hline \multicolumn{5}{|c|}{ Group A } \\
\hline 2272 & -1.80 & -0.72 & -1.95 & -4.00 \\
\hline 2273 & -1.44 & -0.90 & -1.59 & -4.06 \\
\hline 2275 & -4.16 & -1.49 & -4.31 & -4.29 \\
\hline 2276 & -1.26 & -1.23 & -1.41 & -4.53 \\
\hline $2278 \mathrm{a}$ & -5.49 & -2.41 & -5.64 & -4.74 \\
\hline $2278 b$ & -5.15 & -2.05 & -5.30 & -4.69 \\
\hline 2280 & -2.65 & -1.41 & -2.80 & -4.09 \\
\hline 2282 & -4.14 & -2.24 & -4.29 & -5.75 \\
\hline 2283 & $*$ & -2.02 & $*$ & -4.31 \\
\hline 2284 & $*$ & -1.10 & $*$ & -3.85 \\
\hline 2285 & -4.50 & -1.60 & -4.66 & -3.95 \\
\hline 2289 & -2.96 & -1.37 & -3.11 & -4.13 \\
\hline 2290 & -2.88 & -1.36 & -3.03 & -4.11 \\
\hline 2291 & -4.95 & -2.09 & -5.10 & -4.77 \\
\hline 2292 & -0.79 & -1.27 & -0.94 & -4.73 \\
\hline 2293 & -3.31 & -1.88 & -3.46 & -4.65 \\
\hline 2294 & -2.98 & -1.49 & -3.13 & -4.17 \\
\hline 2295 & -2.31 & -1.53 & -2.45 & -4.17 \\
\hline 2296 & -2.65 & -1.73 & -2.80 & -4.12 \\
\hline 2297 & -0.79 & -0.80 & -0.94 & -3.94 \\
\hline \multicolumn{5}{|c|}{ Group B } \\
\hline 2277 & -5.14 & -3.51 & -5.29 & -7.61 \\
\hline 2279 & -4.15 & -3.07 & -4.29 & -7.47 \\
\hline 2281 & -5.43 & -2.12 & -5.58 & -5.16 \\
\hline \multicolumn{5}{|c|}{ Surface Water } \\
\hline Dwyer's Ck. & -2.61 & -1.79 & -2.76 & -4.97 \\
\hline Lambing Hut Ck. & -2.27 & -0.85 & -2.42 & -3.93 \\
\hline
\end{tabular}

${ }^{*} \mathrm{pH}$ too low for analysis.

for weathering rate estimations as in some other geochemical mass balance studies (e.g. Turner et al., 2010).

\subsection{Geochemical mass balance II - Group B groundwater samples}

For three of the samples, $\mathrm{Na}^{+}, \mathrm{SO}_{4}^{2-}$ and $\mathrm{H}_{4} \mathrm{SiO}_{4}$ concentrations were still positive after subtracting rainfall inputs
(Table 5); these samples are termed Group B. The strong $\mathrm{SO}_{4}^{2-}$ excess after normalisation and rainfall subtraction is attributed to pyrite oxidation. Pyrite is present in small amounts in the granite (Atkinson, 1976), but pyrite oxidation is evident in only a few of the groundwater samples in this study. This is because pyrite distribution in the granite is very heterogeneous and/or because the resulting $\mathrm{SO}_{4}^{2-}$ addition is small relative to the effect of evapotranspiration. Acidity released by pyrite oxidation (Eq. 3) has attacked plagioclase in the Dwyer Granite (Eq. 4); biotite and K-feldspar are present in much smaller amounts than plagioclase (Hergt et al., 2007), and so do not contribute significantly to the water composition.

$$
\begin{aligned}
& 2.31 \mathrm{FeS}_{2}+8.07 \mathrm{O}_{2}+2.31 \mathrm{H}_{2} \mathrm{O} \\
& =2.31 \mathrm{Fe}^{2+}+\underline{4.61} \mathrm{SO}_{4}{ }^{2-}+3.61 \mathrm{H}^{+}
\end{aligned}
$$

The plagioclase weathering reaction (Eq. 4) results in the formation of kaolinite (the only clay mineral identified in the soil using XRD), and is balanced using the average composition of plagioclase in the Dwyer Granite $\left(\mathrm{An}_{18-30}\right.$; Hergt et al., 2007) and the excess $\mathrm{Na}^{+}$levels present in Group $\mathrm{B}$ samples (underlined). The $\mathrm{H}^{+}$released by pyrite oxidation is less than that consumed by plagioclase weathering, indicating an additional source of acidity, probably carbonic acid from $\mathrm{CO}_{2}$-rich soil water (Garrels and Mackenzie, 1967):

$$
\begin{aligned}
& 5.95 \mathrm{Na}_{0.76} \mathrm{Ca}_{0.24} \mathrm{Al}_{1.24} \mathrm{Si}_{2.76} \mathrm{O}_{8}+7.38 \mathrm{H}^{+}+3.69 \mathrm{H}_{2} \mathrm{O} \\
& =3.69 \mathrm{Al}_{2} \mathrm{Si}_{2} \mathrm{O}_{5}(\mathrm{OH})_{4}+\underline{4.52} \mathrm{Na}^{+} \\
& +1.43 \mathrm{Ca}^{2+}+9.04 \mathrm{SiO}_{2} .
\end{aligned}
$$

Once the ions released by these two weathering reactions are accounted for, the Group B samples are depleted in all chemical species, preventing the use of additional mineral weathering reactions in the mass balance (Table 7).

Two of the Group B samples are modern (tritium concentrations of 0.304 and $0.339 \mathrm{Bqkg}^{-1}$; Fig. $7 \mathrm{~b}$ ) and are very dilute (150-220 $\mu \mathrm{Scm}^{-1}$; Table 1), showing minimal influence of evapotranspiration. This suggests that they were recharged 
Table 9. Comparison of plant nutrient requirements with percentage species depletion in groundwater (calculated by dividing median rainfall composition by depletion values for Group A groundwater in Table 5).

\begin{tabular}{lrrrrrrr}
\hline Group A (20 samples) & $\mathrm{K}^{+}$ & $\mathrm{Ca}^{2+}$ & $\mathrm{Mg}^{2+}$ & $\mathrm{SO}_{4}^{2-}$ & $\mathrm{HCO}_{3}^{-}$ & $\mathrm{H}_{4} \mathrm{SiO}_{4}$ & $\mathrm{Na}^{+}$ \\
\hline $\begin{array}{l}\text { Percentage of rainfall } \\
\text { composition (molar) }\end{array}$ & 1.9 & 7.3 & 4.5 & 6.0 & 11.9 & 0.2 & 32.5 \\
$\begin{array}{l}\text { Percentage of rainfall input } \\
\text { depleted in groundwater }\end{array}$ & 93.8 & 83.7 & 14.7 & 81.7 & 99.0 & 100 & 18.4 \\
$\begin{array}{l}\text { Macro- or micro- nutrient } \\
\text { (Atwell et al., 1999; }\end{array}$ & macro & macro & macro & macro & macro & micro & beneficial \\
Marschner, 1989) & & & & & & & \\
\hline
\end{tabular}

(a)

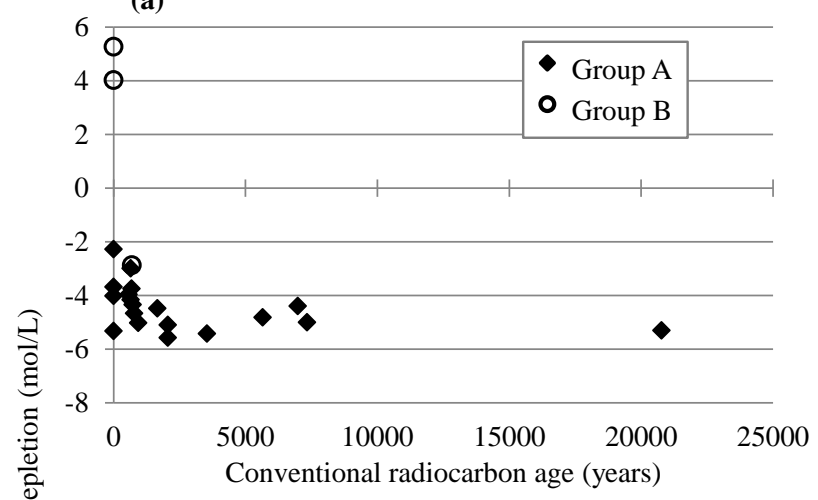

(c)

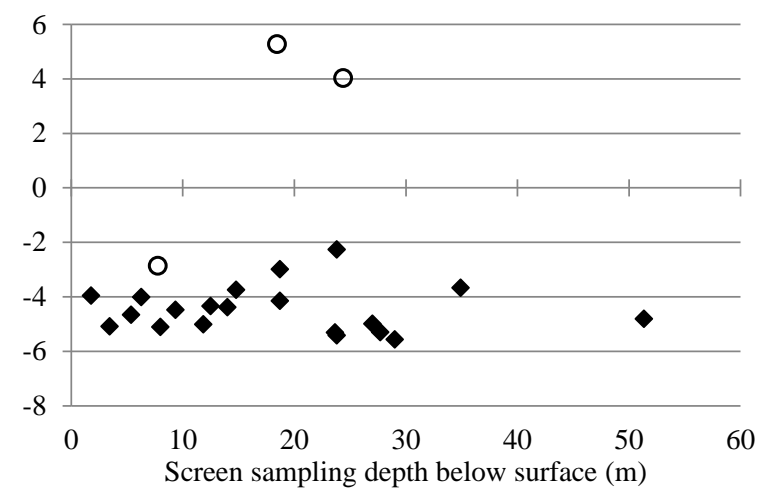

(b)

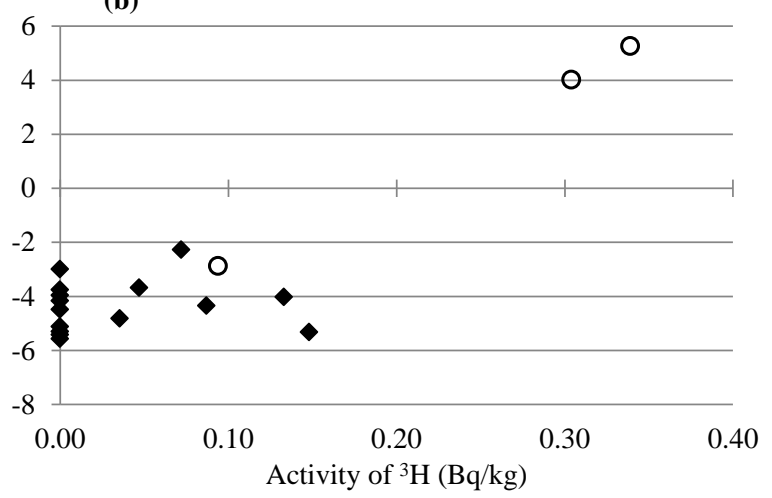

(d)

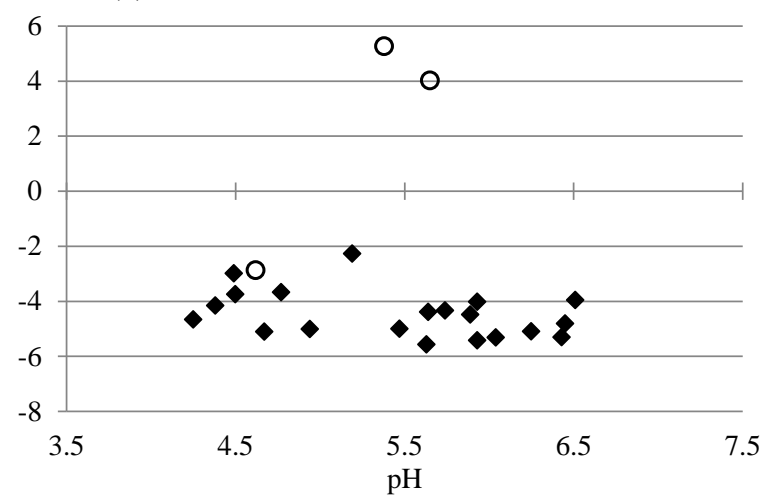

Figure 7. The cation depletion in the groundwater samples (after subtracting rainfall and rock weathering inputs) shows no clear trend with age (a, b), sampling depth (c), or $\mathrm{pH}(\mathbf{d})$. The zero values in graphs (a) and (b) indicate values outside the range of the respective dating techniques. A detectable level of tritium indicates that the water is "modern" - recharged in the last $\sim 50$ yr (Clark and Fritz, 1997; see Sect. 3.1.3). Those samples that contained measurable tritium and also sufficient ${ }^{14} \mathrm{C}$ to give a radiocarbon date indicate mixing of modern and older groundwater (Table 2).

rapidly, despite their sampling depths (Fig. 7c), along preferential pathways, most likely open fractures in surface outcrops of the granite. This is clearly visible in the groundwater potentiometric surface from late 2012, where preferential flow paths through these two bores are evident compared to the surrounding bores (Fig. 8). They show evidence of pyrite oxidation, probably facilitated by the rapid influx of oxygenated waters, and this reaction releases relatively large amounts of acidity quickly, so it has caused rapid alteration of weatherable minerals in the granite, accounting for the evidence of plagioclase weathering in these samples (Table 5).

The third sample in Group B (2281) represents mixing between modern dilute water with a rock-weathering signature and detectable levels of tritium, and older water containing datable radiocarbon (see Sect. 3.1.3; Figs. 4 and 7a). As a result some rock-weathering input is evident in this sample, but it is not as obvious as in the other two samples of Group B. 


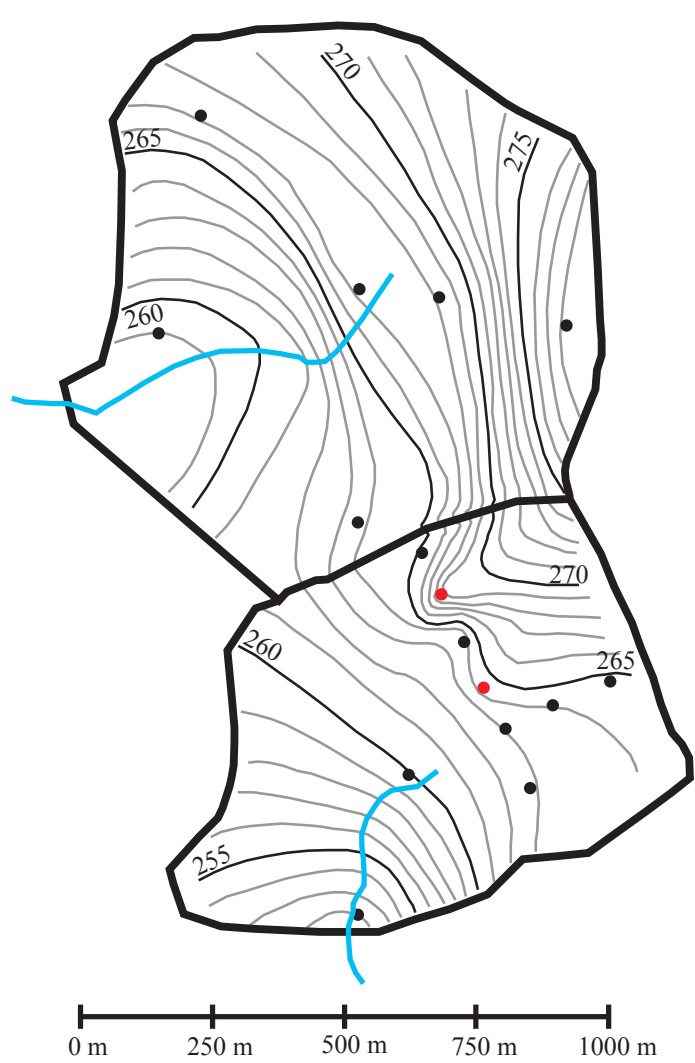

Figure 8. Groundwater potentiometric surface map for September 2012. Note the northeast corner of the farm catchment where the fracture flow evident in bores 2279 and 2277 (red dots) exhibit preferential pathways in the equipotential lines. See Fig. 1 for location.

\subsubsection{Predicted groundwater inputs from granite weathering}

$\mathrm{TiO}_{2}, \mathrm{FeO}$ and $\mathrm{SiO}_{2}$ all plot along the $\mathrm{Zr}$ isocon, suggesting they have not moved significantly during weathering (within the uncertainty due to compositional variations; Fig. 6; Grant, 1986; Webb and Golding, 1998). The small gain in $\mathrm{Al}$ is not believed to be significant. $\mathrm{CaO}, \mathrm{K}_{2} \mathrm{O}, \mathrm{MgO}$, $\mathrm{MnO}$ and $\mathrm{Na}_{2} \mathrm{O}$ are all strongly depleted in the weathered granite saprolite (by 52-96\%; Table 4). These elements are lost into the groundwater, and so the groundwater should therefore be enriched in these species with respect to rainfall. However, for the majority of groundwater samples, the geochemical mass balance shows that all species are depleted (Table 5). This has also been observed in a nearby catchment where $\mathrm{Ca}^{2+}, \mathrm{HCO}_{3}^{-}, \mathrm{K}^{+}, \mathrm{Mg}^{2+}$ and $\mathrm{Na}^{+}$are all depleted in the groundwater (Edwards and Webb, 2009). Even the Group $\mathrm{B}$ groundwater samples in this study are enriched in only two species $\left(\mathrm{Na}^{+}\right.$and $\mathrm{SO}_{4}^{2-}$; Table 7).

\subsection{Depletion of chemical species}

It is evident that one or more processes overwrite the influence of rock weathering on the hydrochemistry, causing depletion of all species in the groundwater. This depletion could be due to mineral precipitation (Adams et al., 2001; Bennetts et al., 2006; Bullen et al., 1996), cation exchange (Adams et al., 2001; Bennetts et al., 2007), or plant uptake (Edwards and Webb, 2009).

Mineral precipitation can cause species depletion, but PHREEQC equilibrium modelling (to determine saturation indices) shows that groundwater and surface water saturation indices in the study area for all likely minerals (calcite, gypsum, aragonite and halite), are all strongly negative (Table 8). XRD analyses of the soil profile in the study area and nearby areas found that none of these or other minerals are present, and only kaolinite is being formed by the weathering process, which is already accounted for in geochemical mass balance II (see Sect. 4.2; Edwards and Webb, 2009).

Cation exchange on clays cannot be causing the depletion in the Group A samples because there is no evidence of cation enrichment in the water compositions to balance the removal of the cation which is being substituted (Table 5, Fig. 5); this includes $\mathrm{H}^{+}$as shown by the absence of a relationship between $\mathrm{pH}$ and cation depletion (Fig. 7d).

Thus water-rock interactions cannot explain the mass balance results, and the depletion observed here is instead ascribed to plant uptake. As outlined in the introduction, plants use all of the depleted elements from this study for normal function. This is verified by the amount of each element that is depleted expressed as a percentage of what is delivered in rainfall. The depletion of each element, as a percentage of the total input in rainfall, generally matches the macro-/micronutrient demands of plants (Table 9). It is notable that the percentage depletion for $\mathrm{Na}$ from rainfall is relatively low, but the actual amount removed is substantial, because $\mathrm{Na}$ is the dominant cation supplied in rainfall (Table 3).

Rapid depletion by plant uptake within the soil has been previously documented in southwest Victoria, with most depletion occurring within the top $50 \mathrm{~cm}$ of the regolith, indicating that vegetation is influencing the chemistry of groundwater as it infiltrates through the root zone (Edwards and Webb, 2009). This has also been observed in granitic catchments north of the current study site, where groundwater composition was shown to be directly influenced by depletion by biomass uptake (Hagerty, 2013).

The overall hydrochemical influence of vegetation extends from the canopy (due to the input of exuded salts on leaf surfaces; Ugolini et al., 1977) to the bottom of the roots, which may reach the water table. Plants also influence groundwater and surface water chemistry through the impact of transpiration, which increases the overall salinity (Bennetts et al., 2006; Herczeg et al., 2001). In southeast Australia this acts in concert with evaporation and generally greatly exceeds rainfall to therefore dominate the hydrochemistry (Fig. 2; 
Bennetts et al., 2006; Edwards and Webb, 2009; Herczeg et al., 2001; Raiber et al., 2009). Evapotranspiration is of lower importance in chemical weathering studies carried out in high rainfall, Northern Hemisphere regions because it is less than rainfall in all these study areas, with rock-water interactions found to be more significant (Einarsson, 1972; Garrels and Mackenzie, 1967; Gislason et al., 1996; Moulton et al., 2000; Rasmussen et al., 2011; Taylor and Velbel, 1991; Velbel and Price, 2007; White and Blum, 1995; White et al., 2002). In contrast, water-rock interactions have only localised effects in this study, observed as excess $\mathrm{Na}^{+}$and $\mathrm{SO}_{4}^{2-}$ due to plagioclase weathering and pyrite oxidation (see Sect. 4.2), with the vast majority of samples having a signature of element depletion due to the overriding impact of plant uptake.

\subsection{Export of chemical species}

Depletion of elements in the soil and the groundwater and surface water over the Dwyer Granite indicates that the vegetation is mining the hydrological system, removing more nutrients than are being introduced through precipitation and rock weathering. As a result, although the saprolite is depleted in mobile elements compared to unweathered bedrock, the groundwater is not enriched but depleted in these species, because plant uptake has removed virtually all the elements supplied to the groundwater by rock weathering.

Important nutrient species utilised by the vegetation are recycled; in Eucalypt species like those growing in the study area, leaf litter, bark shedding, and dead wood re-introduce large amounts of nutrient species back into the system (Attiwill, 1978; Feikema et al., 2012). Continued input through precipitation and rock weathering, together with recycling by vegetation, should result in a buildup of elements in the system, but there is no evidence of this occurring in the isocon plot (Fig. 6), or the groundwater and surface water mass balance calculations (Tables 5-7), so export of elements must be taking place. The erosion of particulate organic matter is a potential export process, but because of generally low flows in southeast Australian rivers, large scale removal of organic matter occurs only during infrequent flood events and is therefore unlikely to be the major process responsible for export of nutrients from the system (Edwards and Webb, 2009; McMahon et al., 1987).

A much more effective process of nutrient removal is through fire. Burning clears away the forest understory and fallen bark, branches and leaf litter (Atwell et al., 1999; Gammage, 2011). Nutrients are exported within particles of smoke, which are so widely dispersed that the proportion of exported elements returned as dry deposition to any particular area will be minor. Nutrients are also rapidly leached out of the ash remaining on the ground; nutrient pulses in surface water following bush fires are well documented in southeastern Australia (Chessman, 1986; Lane et al., 2008), and are
Table 10. Burning frequency required for depletion of common elements in groundwater. Rainfall deficit from Table 5 (Group A groundwater); leaf biomass values for Eucalyptus camaldulensis from Briggs and Maher (1983) and Fekeima et al. (2012); see text for explanation.

\begin{tabular}{lrrrrr}
\hline & $\mathrm{Ca}$ & $\mathrm{K}$ & $\mathrm{Mg}$ & $\mathrm{Na}$ & $\mathrm{S}$ \\
\hline $\begin{array}{l}\text { Rainfall input } \\
\left(\mathrm{kg} \mathrm{ha}^{-1} \text { year }\right.\end{array}$
\end{tabular}

also evident in water quality data from streams around the study site after recent bushfires in the area.

Recharge of the majority of groundwater samples (15) collected in this study occurred prior to European settlement, during the Late Pleistocene and Holocene (Fig. 7a). Fire has been a feature of the Australian landscape during this time, as shown by charcoal distribution in sediment cores throughout Australia, and has been attributed to anthropogenic promotion of fire across most of Australia for the last $\sim 45000 \mathrm{yr}$ (Bowman, 1998; Edney et al., 1990; Head, 1988, 1989; Kershaw, 1986; Kershaw et al., 1991; Lynch et al., 2007; Mooney et al., 2011). Controlled fire was used regularly by Aboriginal land users in Australia to increase the productivity of the land, burning areas as often as once every 2 to 4 years, to the extent that the pre-European settlement forests were generally very open and mostly devoid of understory (Gammage, 2011). Fire encourages seed release, seed germination and the stimulation of budding and flowering, with many Australian plant species dependent on fire for seed propagation and fruit production (Bowman, 1998; Gammage, 2011; Gott, 2005). Newly germinated bulbs, seeds and grasses promoted by burning the land can soon attract animals, expose their tracks and increase their visibility for hunting, improving the availability of this food source for Aboriginal land users (Attiwill et al., 1978; Bowman, 1998).

To calculate the burning frequency that would account for the chemical species depletion observed in the groundwater (Table 10), the quantities in the leaf biomass of Eucalyptus camaldulensis, a common tree species at the study site prior to European clearance, were divided by the rainfall deficit from Table 5. The leaf biomass values were derived from the average composition in E. camaldulensis hybrids (Fekeima et al., 2012) and the median values of yearly leaf litter $\left(163000 \mathrm{~kg} \mathrm{ha}^{-1}\right)$ in an E. camaldulensis swamp in NSW, approximately $450 \mathrm{~km}$ northeast of the study site $\left(33^{\circ} 51^{\prime} \mathrm{S}, 144^{\circ} 50^{\prime} \mathrm{E}\right.$; Briggs and Maher, 1983); the tree density is believed to be similar to that of the pre-European forest in the study area. 
The calculated fire frequencies (in the order of every 1 to 10 years) are probably too high, as they assume that $100 \%$ of elements stored in the biomass are exported during the fire. Furthermore, these fire frequencies underestimate the biomass lost in fires, because although leaf mass represents the bulk of the tree material removed during fire, other biomass such as bark and smaller limbs are also consumed. Gammage (2011) estimated that Aboriginal burning occurred in landscapes like that of the study area as frequently as every 2 to 4 years. This broadly matches the calculated fire frequencies from Table 10, where, for example, the vegetation foliage would need to be burned every 8 years to account for the observed depletion of $\mathrm{K}$ in the groundwater based on average rainfall $\mathrm{K}$ compositions.

Many Australian plant species are fire adapted, recovering rapidly after fire, especially when competition species are eliminated, as the ash is a rich source of plant nutrients (Atwell et al., 1999; Gammage, 2011). Fire was common in southwest Victoria throughout the time that most of the older groundwater samples at the study site were being recharged, providing a strong link between Aboriginal land management practices and groundwater composition.

Hydrochemical studies in higher rainfall, Northern Hemisphere areas have not shown a significant influence of plant uptake and nutrient export on the water composition; rockweathering processes dominate (Garrels and Mackenzie, 1967; Moulton et al., 2000; Taylor and Velbel, 1991; Turner et al., 2010; Velbel and Price, 2007; White et al., 2002). This is due either to reduced uptake by the vegetation species compared to Australian Eucalypts, and/or the lack of large, regular export events. The larger input from rock-weathering is not due solely to greater element availability in rocks freshly exposed by recent glacial processes, as some of the study areas are beyond the limit of the Pleistocene glaciations (Garrels and Mackenzie, 1967; Taylor and Velbel, 1991; Velbel and Price, 2007; White et al., 2002).

Some of the groundwater samples in this study (nine including mixed samples, Fig. 7b) are young enough to have been recharged following European settlement in the area, but show the same depletion pattern as the older samples. Following extensive land clearance in the area after 1869 there has been a decrease in the regularity of bush fires, but the intensity of the fires has increased, and elements continue to be removed from the system through this process. In addition, nutrient species are exported by crop harvesting and grazing (Clymans et al., 2011; Heckman et al., 2003). Thus while modern agriculture is a significantly different land management practice to that of pre-European Aboriginals, the outcome of nutrient depletion of groundwater in the study area is the same.

\section{Conclusions}

At the study site a geochemical mass balance was carried out to investigate the role of granite weathering on groundwater and surface water geochemical evolution. A small number of samples from this site showed the influence of granite weathering (through pyrite oxidation), but for the majority of the samples, once rainfall inputs were taken into account, all major cations and anions are depleted. Cation exchange and mineral precipitation are ruled out as possible causes for this depletion, with the most likely mechanism being uptake by plant biomass.

Continued uptake of chemical species by vegetation should result in a build-up of these species in the soil and biomass, but in fact the soil is depleted as well, so there must be an export mechanism. For this study site we hypothesise that regular burning by Aboriginal land users was responsible for much of this export, given that the majority of the groundwater samples were recharged before European settlement.

This study has shown that the uptake of species through vegetation growth and removal through fire regimes has a dominating influence on groundwater and surface water chemistry and on geochemical cycling in southeast Australia. These results are likely to be applicable to silicate terrains in similar low precipitation, high transpiration biomes elsewhere in Australia and globally, and this should be explored further.

Acknowledgements. We would like to acknowledge Phil Cook and Peter Hekmeijer at the Department of Primary Industries Victoria, our collaborators in the National Centre for Groundwater Research and Training (of which this research is part of program $4-$ http://www.groundwater.com.au) for funding and support, the Australian Institute of Nuclear Science and Engineering (AINSE - grant number AINSTU0710) for funding and support, and funding from the State of Victoria through the Department of Environment and Primary Industries, Future Farming Systems Research Division.

We would like to thank Dr Jason Price and all the other anonymous reviewers involved with this manuscript throughout the review process, whose highly constructive feedback have led to the final production of this paper as it is now.

Neither the NCGRT, AINSE nor DEPI Victoria (as funding sources) were involved in the design of this specific study, nor were they involved in the collection or analysis of the resulting data.

Edited by: C. P. Slomp

\section{References}

Adams, S., Titus, R., Pieterson, K., Tredoux, G., and Harris, C.: Hydrochemical characteristics of aquifers near Sutherland, Western Karoo, South Africa, J. Hydrol., 241, 91-109, 2001.

Adelana, M., Dresel, E., Hekmeijer, P., Zydor, H., Webb, J., Reynolds, M., and Ryan, M.: A comparison of streamflow and water balances in adjacent farmland and forest catchments in 
South-Western Victoria, Australia, Hydrol. Process., accepted, 2014.

Atkinson, P. L.: Geology and geochemistry of the Victoria Valley Batholith, Grampians Ranges, South Eastern Australia, Honours Thesis, La Trobe University, Melbourne, Australia, 1976.

Attiwill, P. M., Gurthrie, H. B., and Leuning, R.: Nutrient cycling in a Eucalyptus obliqua (L'Hérit) forest, I. Litter production and nutrient return, Aust. J. Bot., 26, 79-91, 1978.

Atwell, B., Kriedemann, P., and Turnbull, C.: Plants in Action, Macmillan Publishing, Melbourne, 1999.

Bennetts, D. A., Webb, J. A., Stone, D. J. M., and Hill, D. M.: Understanding the salinization process for groundwater in an area of South-Eastern Australia, using hydrochemical and isotopic evidence, J. Hydrol., 323, 178-192, 2006.

Bennetts, D. A., Webb, J. A., McCaskill, M., and Zollinger, R.: Dryland salinity processes within the discharge zone of a local groundwater system, Southeastern Australia, Hydrogeol. J., 15, 1197-1210, 2007.

Bormann, M. E.: Temporal and spatial trends in rainwater chemistry across Central and Western Victoria, Honours Thesis, La Trobe University, Melbourne, Australia, 2004.

Boutt, D. F., Diggins, P., and Mabee, S.: A field study (Massachusetts, USA) of the factors controlling the depth of groundwater flow systems in crystalline fractured-rock terrain, Hydrogeol. J., 18, 1839-1854, 2010.

Bowman, D. M. J. S: The impact of Aboriginal landscape burning on the Australia biota, New Phytol., 140, 385-410, 1998.

Bricker, O. P., Jones, B. F., and Bowser, C. J.: Mass-balance approach to interpreting weathering reactions in watershed systems, in: Treatise in Geochemistry, edited by: Holland, H. D. and Turekain, K. K., Elsevier Permagon, Amsterdam, 119-132, 2004.

Briggs, S. V. and Maher, M. T.: Litter fall and leaf decomposition in a river red gum (Eucalyptus camaldulensis) swamp, Aust. J. Bot., 31, 307-316, 1983.

Brimhall, G. H., Lewis, C. J., Ford, C., Bratt, J., Taylor, G., and Warin, O.: Quantitative geochemical approach to pedogenesis: importance of parent material reduction, volumetric expansion, and eolian influx in lateritization, Geoderma, 51, 51-91, 1991.

Bullen, T. D., Krabbenhoft, D. P., and Kendall, C.: Kinetic and mineralogic controls of groundwater chemistry and $87 \mathrm{Sr} / 86 \mathrm{Sr}$ in a sandy silicate aquifer, Northern Wisconsin, USA, Geochim. Cosmochim. Ac., 60, 1807-1821, 1996.

Calmels, D., Galy, A., Hovius, N., Bickle, M., West, A. J., Chen, M.-C., and Chapman, H.: contribution of deep groundwater to the weathering budget in a rapidly eroding mountain belt, Taiwan., Earth Planet. Sc. Lett., 303, 48-58, 2011.

Camporese, M., Dean, J. F., Dresel, P. E., Webb, J., and Daly, E.: Hydrological modelling of paired catchments with competing land uses, Proceedings of the 20th International Congress on Modelling and Simulation, Adelaide, Australia, 1-6 December, 1819-1825, 2013.

Cartwright, I.: Using groundwater geochemistry and environmental isotopes to assess the correction of ${ }^{14} \mathrm{C}$ ages in a silicatedominated aquifer system, J. Hydrol., 382, 174-187, 2010.

Chapelle, F. H.: Geochemistry of groundwater, in: Readings from the Treatise on Geochemistry, edited by: Holland, H. D. and Turekian, K. K., Elsevier, Amsterdam, 289-315, 2010.
Chessman, B. C.: Impact of wildfires on river water quality in East Gippsland, Victoria, Aus. J. Mar. Fresh. Res., 37, 399-420, 1986.

Clark, I. D. and Fritz, P.: Environmental Isotopes in Hydrogeology, Taylor and Francis Group, New York, 1997.

Cleaves, E. T., Godfrey, A. E., and Bricker, O. P.: Geochemical balance of a small watershed and its geomorphic implications, Geol Soc. Am. Bull., 81, 3015-3032, 1970.

Clymans, W., Struyf, E., Govers, G., Vandevenne, F., and Conley, D. J.: Anthropogenic impact on amorphous silica pools in temperate soils, Biogeosciences, 8, 2281-2293, doi:10.5194/bg-8-22812011, 2011.

Cook, P. G.: A Guide to Regional Groundwater Flow in Fractured Rock Aquifers, CSIRO Land and Water, Adelaide, SA, 2003.

Dept. Sustainability and Environment: Groundwater SAFE: Secure Allocations, Future Entitlements, Victorian Gov. Dept. of Sustainability and Environment, Melbourne, 2012.

Dresel, P. E., Hekmeijer, P., Dean, J. F., Harvey, W., Webb, J. A., and Cook, P.: Use of laserscan technology to analyse topography and flow in a weir pool, Hydrol. Earth Syst. Sci., 16, 2703-2708, doi:10.5194/hess-16-2703-2012, 2012.

Edney, P. A., Kershaw, A. P., and De Deckker, P.: A Late Pleistocene and Holocene vegetation and environmental record from Lake Wangoom, western plains of Victoria, Australia, Palaeogeogr. Palaeocl., 80, 325-343, 1990.

Edwards, M. and Webb, J.: The importance of unsaturated zone biogeochemical processes in determining groundwater composition, Southeastern Australia, Hydrogeol. J., 17, 1359-1374, 2009.

Einarsson, M. A.: Evaporation and Potential Evapotranspiration in Iceland, Icelandic Meterological Office, Reykjavik, 1972.

Feikema, P. M., Sasse, J. M., and Bandara, G. D.: Chloride content and biomass partitioning in Eucalyptus hybrids grown on saline sites, New Forest, 43, 89-107, 2012.

Fink, D., Hotchkis, M., Hua, Q., Jacobsen, G., Smith, A. M., Zoppi, U., Child, D., Mifsud, C., van der Gaast, H., Williams, A., and Williams, M.: The ANTARES AMS facility at ANSTO, NIM B, 223/224, 109-115, 2004.

Gammage, B.: The Biggest Estate on Earth, Allen and Unwin, Sydney, Australia, 2011.

Gardner, T. W., Webb, J. A., Davis, A. G., Cassell, E. J., Pezzia, C., Merritts, D. J. and Smith, B.: Late Pleistocene landscape response to climate change: eolian and alluvial fan deposition, southeastern Victoria, Australia. Quaternary Sci. Rev., 25, 1552 1569, 2006.

Garrels, R. M. and Mackenzie, F. T.: Origin of the chemical compositions of some springs and lakes. Equilibrium concepts in natural water systems, Adv. Chem. Ser., 67, 222-242, 1967.

Gislason, S. R., Arnórsson, S., and Ármannsson, H.: Chemical weathering of basalt in Southwest Iceland: effects of runoff, age of rocks and vegetative/glacial cover, Am. J. Sci., 296, 837-907, 1996.

Gott, B.: Aboriginal fire management in South-Eastern Australia: aims and frequency, J. Biogeogr., 32, 1203-1208, 2005.

Grant, J. A.: The isocon diagram - a simple solution to Gresens' equation for metasomatic alteration, Econ. Geol., 81, 19761982, 1986.

Hagerty, S. K.: The hydrogeology, hydrogeochemistry and hydrology of granitic landscapes in the upper Wimmera Catchment, Western Victoria, Australia, $\mathrm{PhD}$ thesis, La Trobe University Bundoora, VIC, 2013. 
Head, L.: Holocene vegetation and environmental history of the Discovery Bay region, South-Western Victoria, Aust. J. Ecol., 13, 21-49, 1988.

Head, L.: Prehistoric Aboriginal impacts on Australian vegetation: an assessment of the evidence, Aust. Geogr., 20, 37-46, 1989.

Heckman, J. R., Sims, J. T., Beegle, D. B., Coale, F. J., Herbert, S. J., Bruulsema, T. W., and Bamka, W. J.: Nutrient removal by corn grain harvest, Agron. J., 95, 587-591, 2003.

Hem, J. D.: Study and Interpretation of the Chemical Characteristics of Natural Water, US Geological Survey Water-Supply Paper 2254, 1985.

Herczeg, A. L., Dogramcai, S. S., and Leaney, F. W. J.: Origin of dissolved salts in a large, semi-arid groundwater system: murray basin, Australia, Mar. Freshwater Res., 52, 41-52, 2001.

Hergt, J., Woodhead, J., and Schofield, A.: A-type magmatism in the Western Lachlan Fold Belt? A study of granites and rhyolites from the Grampians region, Western Victoria, Lithos, 97, 122139, 2007.

Hua, Q., Jacobsen, G. E., Zoppi, U., Lawson, E. M., Williams, A. A., Smith, A. M., and Mc-Mann, M. J.: Progress in radiocarbon target preparation at the ANTARES AMS Centre, Radiocarbon, 43, 275-282, 2001

Hutton, J. T.: Chloride in rainwater in relation to distance from ocean. Search, 7, 207-208, 1976.

Hutton, J. T. and Leslie, T. I.: Accession of non-nitrogenous ions dissolved in rainwater to soils in Victoria, Aust. J. Agr. Res. 9, 59-84, 1958.

Kershaw, A. P.: Climatic change and Aboriginal burning in NorthEast Australia during the last two glacial/interglacial cycles, Nature, 322, 47-49, 1986.

Kershaw, A. P., D'Costa, D. M., McEwen Mason, J. R. C., and Wagstaff, B. E.: Palynological evidence for Quaternary vegetation and environments of mainland Southeastern Australia, Quaternary Sci. Rev., 10, 391-404, 1991.

Lane, P. N. J., Sheridan, G. J., Noske, P. J., and Sherwin, C. B.: Phosphorus and nitrogen exports from SE Australian forests following wildfire, J. Hydrol., 361, 186-198, 2008.

Locsey, K. L., Grigorescu, M., and Cox, M. E.: Water-rock interactions: an investigation of the relationships between mineralogy and groundwater composition and flow in a subtropical basalt aquifer, Aquat. Geochem., 18, 45-75, 2012.

Lynch, A. H., Beringer, J., Kershaw, P., Marshall, A., Mooney, S., Tapper, N., Turney, C., and Van Der Kaars, S.: Using the paleorecord to evaluate climate and fire interactions in Australia, Annu. Rev. Earth Planet. Sci., 35, 215-239, 2007.

Marschner, H.: Mineral Nutrition of Higher Plants, Academic Press Ltd., San Diego, CA, 1989.

McMahon, T. A., Finlayson, B. L., Haines, A., and Srikanthan, R.: Runoff variability: a global perspective, in: The influence of climate change and climatic variability on the hydrologic regime and water resources, edited by: Solomon, S. I., Beran, M., and Hogg, W., IAHS Publication No. 168, 3-11, 1987.

Mooney, S. D., Harrison, S. P., Bartlein, P. J., Daniau, A.-L., Stevenson, J., Brownlie, K. C., Buckman, S., Cupper, M., Luly, J., Black, M., Colhoun, E., D’Costa, D., Dodson, J., Haberle, S., Hope, G. S., Kershaw, P., Kenyon, C., McKenzie, M., and Williams, N.: Late Quaternary fire regimes of Australasia, Quaternary Sci. Rev., 30, 28-46, 2011.
Moulton, K. L., West, J., and Berner, R.: Solute flux and mineral mass balance approaches to the quantification of plant effects on silicate weathering, Am. J. Sci., 300, 539-570, 2000.

Nation, E.: Groundwater Recharge for Agriculture: Rainfall Chemistry Report, Bureau of Rural Sciences, Canberra, 2009.

Plummer, I. N. and Back, W.: The mass balance approach: application to interpreting the chemical evolution of hydrological systems, Am. J. Sci., 280, 130-142, 1980.

Pogge von Strandmann, P. A. E., Burton, K.W., James, R. H., van Calsteren, P., Gislason, S. R., and Sigfússon, B.: The influence of weathering processes on riverine magnesium isotopes in a basaltic terrain, Earth Planet. Sc. Lett., 276, 187-197, 2008.

Raiber, M., Webb, J. A., and Bennetts, D. A.: Strontium isotopes as tracers to delineate aquifer interactions and the influence of rainfall in the basalt plains of Southeastern Australia, J. Hydrol., 367, 188-199, 2009.

Rasmussen, C., Brantley, S., Richter, D., Blum, A., Dixon, J., and White, A. F.: Strong climate and tectonic control on plagioclase weathering in a granitic terrain, Earth Planet. Sc. Lett., 301, 521530, 2011.

Riebe, C. S., Kirchner, J. W., and Finkel, R. C.: Long-term rates of chemical weathering and physical erosion from cosmogenic nuclides and geochemical mass balance, Geochim. Cosmochim. Ac., 67, 4411-4427, 2003.

Taylor, A. B. and Velbel, M. A.: Geochemical mass balances and weathering rates in forested watersheds of the Southern Blue Ridge II. Effects of botanical uptake terms, Geoderma, 51, 2950,1991

Turner, B. F., White, A. F., and Brantley, S. L.: Effects of temperature on silicate weathering: Solute fluxes and chemical weathering in a temperate rain forest watershed, Jamieson Creek, British Columbia, Chem. Geol., 269, 62-78, 2010.

Ugolini, F. C., Minden, R., Dawson, H., and Zachara, J.: An example of soil processes in the Abies amabilis zone of Central Cascades, Washington, Soil Sci., 124, 291-302, 1977.

USEPA: Compendium of ERT Groundwater Sampling Procedures, United States Environmental Protection Agency, Washington, DC, 1999.

VandenBerg, A. H. M.: Rock Unit Names in Western Victoria, Seamless Geology Project, Geological Survey of Victoria Report, Geoscience Victoria, 130 pp., 2009.

Velbel, M. A.: Geochemical mass balances and weathering rates in forested watersheds of the Southern Blue Ridge, Am. J. Sci., 285, 904-930, 1985.

Velbel, M. A. and Price, J. R.: Solute geochemical mass-balances and mineral weathering rates in small watersheds: methodology, recent advances, and future directions, Appl. Geochem., 22, 1682-1700, 2007.

Wallace, A., Mueller, R. T., Wood, R. A., and Soufi, A. M.: Plant uptake of bicarbonate as measured with the ${ }^{11} \mathrm{C}$ isotope, Plant Soil, 51, 431-435, 1979.

Webb, J. A. and Golding, S. D.: Geochemical mass-balance and oxygen-isotope constraints on silcrete formation and its paleoclimatic implications in Southern Australia, J. Sediment Res., 68, 981-993, 1998.

White, A. F. and Blum, A. E.: Effects of climate on chemical weathering in watersheds, Geochim. Cosmochim. Ac., 59, 1729-1747, 1995. 
White, A. F., Blum, A. E., Schulz, M. S., Huntington, T. G., Peters, N. E., and Stonestrom, D. A.: Chemical weathering of the Panola Granite: solute and regolith elemental fluxes and the weathering rate of biotite, Geo. Soc. S. P., 7, 37-59, 2002.

White, M., Oates, A., Barlow, T., Pelikan, M., Brown, J., Rosengren, N., Cheal, D., Sinclair, S., and Stutter, G.: The Vegetation of North-West Victoria, Department of Sustainability and Environment, Melbourne, Australia, 2003.
Wood, W. W. and Low, W. H.: Aqueous geochemistry and diagenesis in the Eastern Snake River Plain aquifer system, Idaho, Geol. Soc. Am. Bull., 97, 1456-1466, 1986. 